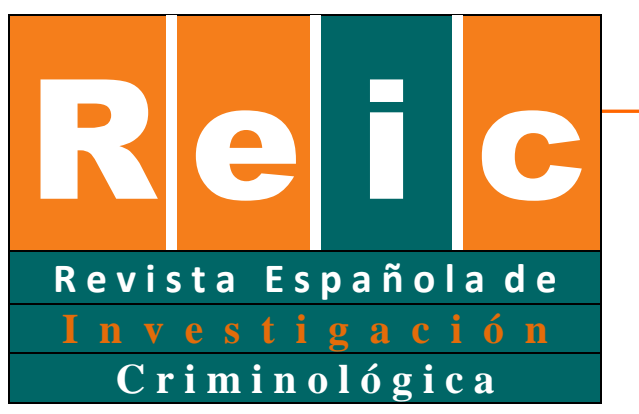

Farrington

\title{
Childhood risk and protective factors for early desisters, late desisters and life-course persistent offenders
}

\author{
David P. Farrington ${ }^{1}$ \\ Institute of Criminology \\ Cambridge University
}

\begin{abstract}
The aim of this article is to investigate the extent to which childhood risk and protective factors predict later persistence or desistance in criminal careers, as it has been argued that childhood factors are not predictive. In the Cambridge Study in Delinquent Development, 411 London males have been followed up from age 8 to age 56. This article investigates age 8-10 risk and protective factors for 37 life-course-persistent offenders (first offense up to age 20, last offense at age 40 or later), 38 late desisters (first offense up to age 20, last offense at age 21-39), 50 early desisters (first and last offenses up to age 20), 41 late onset offenders (first offense at age 21 or later), and 227 nonoffenders. 18 males were excluded from the analysis because they were not at risk of a recorded conviction from age 40 onwards (because of death or emigration). The results showed that several childhood factors predicted persistence compared with desistance. Individual and school risk factors (e.g. low popularity and low school attainment) were the most important predictors of whether an offender up to age 20 persisted after this age or desisted. Family protective factors (e.g. good child-rearing and high parental interest in education) were most important in protecting offenders from becoming life-course-persistent offenders and encouraging desistance before age 40 .
\end{abstract}

Keywords: longitudinal study, risk factors, protective factors, life-course-persistent offenders, desistance.

\footnotetext{
${ }^{1}$ Corresponding author: David P. Farrington, Cambridge University, Institute of Criminology, Sidgwick Avenue, Cambridge CB3 9DA, UK. Telephone 44-1223-872555. Email dpf1@ cam.ac.uk
} 


\section{RESUMEN}

El objetivo principal de este artículo es determinar hasta qué punto los factores de riesgo y de protección de la niñez predicen la persistencia o el abandono en carreras delictivas, ya que se ha argumentado que los factores de la niñez no son predictivos. En el estudio de Cambridge sobre desarrollo delictivo, se realizó el seguimiento a 411 varones londinenses desde los 8 hasta los 56 años. El artículo investiga los factores de riesgo y protección presentes entre los 8 y los 10 años para 37 delincuentes reincidentes (cuyo primer delito habría sido cometido hasta los 20 años y el último delito a la edad de 40 años o más), 38 calificados como desistimiento tardío (primer delito cometido hasta los 20 años y último delito a los 21-39 años), 50 desistimientos tempranos (primer y último delito hasta los 20 años), 41 delincuentes de inicio tardío (primer delito a los 21 años o más) y 227 no delincuentes. 18 varones fueron excluidos del análisis porque no tenían riesgo de una condena registrada a partir de los 40 años (debido a la muerte o la emigración). Los resultados mostraron que varios factores infantiles predijeron la persistencia en comparación con el desistimiento. Los factores de riesgo individuales y escolares (por ejemplo, baja popularidad y bajo rendimiento escolar) fueron los factores predictores más importantes de si un delincuente hasta los 20 años persistió después de esta edad o desistió. Los factores de protección de la familia (por ejemplo, la buena crianza de los hijos y el alto interés de los padres en la educación) fueron los más importantes para proteger a los delincuentes de que se conviertan en delincuentes persistentes en el curso de la vida y alentar el abandono antes de los 40 años.

Palabras clave: Estudio longitudinal, factores de riesgo, factores protectores, delincuentes reincidentes, desistimiento.

\section{Introduction}

\subsection{Influences on desistance}

Most research on desistance focuses on the importance of adult factors (Horney, Tolan, \& Weisburd, 2012; Kazemian \& Farrington, 2015). In particular, it is argued that getting married encourages desistance (for a review, see Theobald, Farrington, \& Piquero, 2019). This was found by Farrington and West (1995) and by Theobald and Farrington (2009, 2010, 2011) in the Cambridge Study in Delinquent Development (CSDD) in London (described later). However, Savolainen (2009) concluded that, in Finland, entering a cohabiting relationship had a greater effect in reducing offending than getting married. Similarly, having a child was followed by a decrease in offending in both studies (Savolainen, 2009; Theobald, Farrington, \& Piquero, 2015). Conversely, separation from a spouse was followed by an increase in offending (Farrington \& West, 1995; Theobald \& Farrington, 2013). 
It is also argued that becoming employed encourages desistance (for a review, see Savolainen, Aaltonen, \& Skardhamar, 2019). Savolainen (2009) found this in Finland, although in a later article Skardhamar and Savolainen (2014) argued that desistance was more likely to precede rather than to follow the transition to employment. In the CSDD, Farrington, Gallagher, Morley St. Ledger, and West (1986) showed that young people committed more crimes (and especially property crimes) during periods of unemployment than during periods of employment.

Moving home is another factor than can encourage desistance (for a review, see Kirk, 2019), especially when offenders move to a better environment (Kirk, 2012). In the CSDD, offending decreased after men moved out of London (Osborn, 1980). There was a decrease not only in convictions but also in self-reported offending. Generally, the men who moved out of London were moving to the leafy Southern counties of Surrey, Sussex, and Kent. Interestingly, Osborn (1980) found that the men who moved out were just as aggressive in their attitudes as the men who stayed in London. He suggested that moving out of London might have reduced criminal opportunities. Another possibility is that moving home disrupted criminal peer influences.

Sampson and Laub (1993) and Laub and Sampson (2003) have propounded some of the most influential theories of desistance. They have proposed that the key theoretical construct is informal social control, which depends on the strength of bonding to conventional institutions such as marriage and employment. An increase in conventional bonding is likely to encourage desistance. Conversely, decreases in undesirable bonding (e.g. to delinquent peers) will also encourage desistance. Getting married, getting a job, and moving home are all turning points that may encourage conventional bonding and the "knifing off" of offenders from previous contexts and associates.

\subsection{Are childhood factors important?}

The influence of childhood factors on desistance has been relatively neglected, despite the numerous longitudinal studies showing childhood influences on offending (see e.g. Farrington, 2015). Also, many theories (e.g. Farrington, 2005) emphasize that offending 
results from an interaction between individual and environmental factors. Sampson and Laub (2005, p.176) explicitly argued that changes in informal social control would influence offending throughout life even after controlling for individual factors. Sampson and Laub (2003) went further in arguing that "life-course-persistent offenders are difficult, if not impossible, to identify prospectively using a wide variety of childhood and adolescent risk factors" (p.584) and "group membership [e.g., adolescence-limited versus life-coursepersistent offenders] is not easily, if at all, predictable from individual, childhood, and adolescent risk factors" (p.585).

Moffitt (1993) first proposed the distinction between adolescence-limited and lifecourse-persistent offenders. These were defined according to ages of onset, criminal career duration, and ages of desistance. Life-course-persistent offenders have a very early age of onset, a very late age of desistance, and a long criminal career duration. In contrast, adolescence-limited offenders have a later age of onset, an earlier age of desistance, and a short criminal career duration. As Moffitt (1993, p.676) pointed out, "timing and duration of the course of antisocial involvement are the defining features in the natural histories of the two proposed types of offenders".

Moffitt (1993) further argued that most of the well-known childhood risk factors for offending influenced the life-course-persistent offenders, not the adolescence-limited offenders. The main factors that predicted life-course-persistent offenders were cognitive deficits, an undercontrolled temperament, hyperactivity, poor parenting, disrupted families, teenage parents, poverty, and low socioeconomic status. In contrast, the main factors that predicted adolescence-limited offenders were the "maturity gap" (their inability to obtain adult rewards such as material goods during their teenage years) and peer influence (especially from life-course-persistent offenders). Consequently, the adolescence-limited offenders desisted when they entered legitimate adult roles and could achieve their desires legally (see Moffitt, 2018, and McGee \& Moffitt, 2019, for recent reviews of her theory).

So why did Sampson and Laub (2003) argue that childhood risk factors did not predict life-course-persistent offenders? They did not define life-course-persistent offenders according to their ages of onset and desistance. Instead, they used the trajectory analysis method of Nagin and Land (1993) to identify six categories of offenders: high rate chronics,

Revista Española de Investigación Criminológica 
moderate rate desisters, classic desisters, moderate rate chronics, low rate chronics 1 , and low rate chronics 2. They assigned individuals to these categories and related them to childhood risk factors. They concluded that "looking at individual differences and parent/child disposition, the pattern is inconsistent and there are no statistically significant differences in means across the six groups of offenders" (Sampson \& Laub, 2003, pp.582583).

There are many problems with Sampson and Laub's (2003) analyses. Skardhamar (2010) has summarized problems of trajectory modeling. For example, even when no groups exist in reality and the data are truly continuous, this technique will yield several categories of offenders. There are often problems of assigning individuals to categories, which is usually achieved using maximum likelihood methods. Bushway and Paternoster (2013, p.215) pointed out:

We know that the overall population experiences a decline in offending with age. The question posed by life-course-persistence research is whether there is evidence that a small group of offenders remains relatively active over the life course. The [trajectory] methods are inherently biased against identifying individuals who follow this type of trajectory because of their (over) reliance on the aggregate population trajectory to describe individual change over time.

Bushway and Paternoster (2013, p.214) also stated:

Sampson and Laub found six groups in the Glueck delinquent boys data that ... all decline to

a point that looks like zero offending by age 70. On the basis of this analysis, Sampson and Laub claim that crime declines with age for even the most active offenders (i.e. desistance from crime is "normative") and thus they suggest that an emphasis on the life-course "desister" rather than the persister should be the next step forward for the field.

\subsection{Defining desistance and life-course-persistent offending}

According to Farrington (2007a, p. 125):

The term desistance has been used both as an empirical variable and as an underlying theoretical construct. As an empirical variable, desistance refers to the observed termination 
of offending. As a theoretical construct, desistance often refers to decreases in the underlying frequency, variety, or seriousness of offending,. Although observed desistance involves a discontinuous change, it is often assumed that the underlying process involves continuous change.

In this article, I will focus on the empirical definition of desistance as the termination of offending, and I will focus on empirical measures of life-course-persistent offending based on criminal career duration. I will not focus on the deceleration or de-escalation of offending (see e.g., Jennings \& Fox, 2019; Kazemian, Farrington, \& Le Blanc, 2009; Loeber, Stouthamer-Loeber, Van Kammen, \& Farrington, 1991). It is not clear that the "high-rate chronic" offenders identified by trajectory analysis necessarily have long criminal careers. Piquero, Sullivan and Farrington (2010) pointed out that trajectory analysis could reveal long-term low-rate offenders as well as short-term high-rate offenders. Therefore, "chronic" offenders (defined according to the total number of offenses committed) may not necessarily be persistent offenders (see Whitten, McGee, Homel, Farrington, \& Ttofi, 2017, 2019).

It seems to me that it is more useful to follow the criminal career approach of Blumstein, Cohen, Roth, and Visher (1986). This specifies that a criminal career has an onset at a certain age, a termination at a later age, and a career duration in between. During the criminal career, offenses are committed at a certain rate or frequency per year, and several researchers have found that this rate is tolerably constant between onset and termination (see e.g. Farrington, MacLeod, \& Piquero, 2016). By definition, no offenses are committed before onset or after termination (desistance). These definitions have been used in much subsequent research on criminal careers (e.g., Piquero, Farrington, Blumstein, 2003, 2007).

It is, of course, difficult to be certain that desistance has occurred. However, based on the prior rate of offending and the number of years since the last offense, it is possible to calculate the probability that desistance has occurred (see e.g. Barnett, Blumstein, \& Farrington, 1989, Figure 1). The probability of reoffending decreases with the time since the last offense, and, after a certain number of years, this probability for an ex-offender may become quite similar to the probability for a nonoffender. For example, Kurlychek, Brame, and Bushway (2006) found that these probabilities became quite similar after about six or seven years, and argued that prior criminal records should not be taken into account (e.g., in

\section{Revista Española de Investigación Criminológica}

Artículo 1, Número 17 (2019)

www.criminologia.net

ISSN: 1696-9219 
employment decisions) after this time (see also Blumstein \& Nakamura, 2009; Bushway, Nieuwbeerta, \& Blokland, 2011).

There has been surprisingly little research on criminal career duration (see Jolliffe, Farrington, Piquero, Loeber, \& Hill, 2017; Jolliffe, Farrington, Piquero, MacLeod, \& Van de Weijer, 2017). Nor has there been much research on residual criminal career duration (Kazemian \& Farrington, 2006, 2018; Kazemian, Le Blanc, Farrington, \& Pease, 2007), despite its policy importance. For example, there may be little point in locking someone up for five years if they are likely to terminate their criminal career within two years; this would be a waste of valuable prison space. Previous CSDD research has reported criminal career duration and ages of onset and desistance (Farrington, 1992a; Farrington et al., 2006; Farrington, Lambert, \& West, 1998; Farrington, Ttofi, Crago, \& Coid, 2014). In the present article, persisters and desisters are defined according to the empirical duration of their criminal careers.

\subsection{Childhood predictors of persisters and desisters}

In the CSDD, Farrington and Hawkins (1991) investigated childhood predictors of offenders versus nonoffenders at age 10-20, an early (age 10-13) versus a later (age 14-20) onset of offending, and persistence versus desistance of offending from age 21 to 32 . They found that low verbal IQ at age 8-10, low paternal involvement in the boy's leisure activities, and low commitment to school predicted persisters as opposed to desisters. Farrington et al. (2006) then defined persisters according to reoffending between ages 21 and 50, and desisters as those who offended at age 10-20 but did not offend subsequently up to age 50. They found that the most important childhood risk factors that predicted persisters compared with desisters were low popularity and low family income.

In the CSDD, Farrington, Ttofi, and Coid (2009) studied nonoffenders, adolescencelimited offenders (convicted only at age 10-20), late-onset offenders (convicted only at age 21-50), and persistent offenders (convicted at both ages 10-20 and 21-50). They found that the average number of convictions of the persistent offenders was 8.1, and their average criminal career duration was 18.4 years. Only one-third of them $(34.3 \%)$ were chronic

\section{Revista Española de Investigación Criminológica}

Artículo 1, Número 17 (2019)

www.criminologia.net

ISSN: 1696-9219 
offenders with 10 or more convictions. The most important childhood risk factors that discriminated between persisters and adolescence-limited offenders were low popularity and harsh parental discipline.

Basto-Pereira, Começanha, Ribeiro, and Maia (2015) completed the first systematic review of early predictors of persistence versus desistance among juvenile delinquents. They found 15 relevant longitudinal studies (including the CSDD), but obtained few consistent results. Walker, Bowen, and Brown (2013) carried out a narrative review of psychological and criminological factors (not necessarily in childhood) associated with desistance from violence. They reported that informal social control (e.g. a stable relationship and employment) was most important, and called for more research on protective factors.

Reviews of the predictors of recidivism may also be relevant, although many offenders who do not recidivate in a typically short follow-up period may not be true desisters. Gendreau, Little, and Goggin (1996) published the first meta-analyses of predictors of adult recidivism, and concluded that the best predictors were in the areas of criminogenic needs, criminal history, social achievement, demographic, and family factors. Cottle, Lee, and Heilbrun (2001) carried out a later meta-analysis of the predictors of juvenile recidivism, and reported that the strongest predictors were in the areas of criminal history, family problems, leisure time, delinquent peers, and conduct problems.

\subsection{Aims}

The main aim of the present article is to investigate childhood (age 8-10) predictors of five categories of males in the CSDD: nonoffenders, late onset offenders (those who start offending between ages 21 and 56), early desisters (those who start and stop offending between ages 10 and 20), late desisters (those who start offending at age 10-20 and stop at age 21-39), and life-course persisters (those who start offending at age 10-20 and continue offending between ages 40 and 56). There has been little prior research comparing early and later desisters, and very few researchers have defined life-course-persistent offenders according to a long criminal career (here, at least 20 years). 
Most prior research in the CSDD on childhood predictors has investigated risk factors. Typically, the "worst" quarter of males on each variable (e.g. low family income or low nonverbal IQ) have been identified as a risk group and compared with the remaining three-quarters. Farrington and Loeber (2000) argued that dichotomized variables are more concordant with the idea of "risk factors", make it easy to communicate results to policy makers and practitioners, can be easily added to produce risk scores and identify multiple risk factor individuals, and make it easy to study and understand interactions between variables. Dichotomization makes it possible to use the odds ratio, which is a more meaningful, interpretable, and realistic measure of the strength of association than the product moment correlation and related statistics such as the percentage of variance explained. The main disadvantage of dichotomization is that information is lost, but conclusions about the relative importance of explanatory variables for offending were not greatly affected by using dichotomous as opposed to continuous variables.

Recent research in the CSDD has investigated protective factors by comparing the "best" quarter of males with the remainder. Farrington and Ttofi (2011) showed how the "worst", middle, and "best" categories predicted convictions at 10-50, while Farrington, Ttofi, and Piquero (2016) carried out similar analyses for convictions at 10-18 (in an article that mainly investigated interaction effects). Some relationships appeared to be nonlinear. For example, low neuroticism predicted a low probability of conviction, but high neuroticism did not predict a high probability of conviction (compared to average neuroticism). Therefore, protective effects of variables could be quite different from risk effects (see also Loeber, Farrington, Stouthamer-Loeber, \& White, 2008, chapter 7).

Both risk and protective factors are studied in this article. It might be expected that risk factors would predict persistence, while protective factors might predict desistance.

\section{Method}

The CSDD is a prospective longitudinal survey of 411 London males from age 8 to age 56. Its results have been described in six books (Farrington, Piquero, \& Jennings, 2013; Piquero et al., 2007; West, 1969, 1982; West \& Farrington, 1973, 1977), and in five summary articles 
(Farrington, 1995b, 2003; Farrington \& West, 1981, 1990; Farrington, Coid, \& West, 2009). The CSDD is now a three-generation study (see Farrington, Ttofi, \& Crago, 2017, 2018; Farrington, Ttofi, Crago, \& Coid, 2015). The convictions of the original males and their wives and female partners (now termed generation 2 or G2) have been compared with the convictions of their parents (generation 1 or G1) and of their children (generation 3 or G3). However, the G3 children are not discussed in this article. The original sample of males is described next, and then the criminal record searches. As the searches were based on identifying particulars obtained in interviews, the interviews are described as well, followed by the childhood factors.

\subsection{The sample of males}

At the time they were first contacted in 1961-62, the boys were all living in a lower-class area of South London. The vast majority of the sample was chosen by taking all the boys who were then aged 8-9 and on the registers of six state primary schools within a one mile radius of a research office which had been established. In addition to 399 boys from these six schools, 12 boys from a local school for educationally subnormal children were included in the sample, in an attempt to make it more representative of the population of boys living in the area. Therefore, the boys were not a probability sample drawn from a population, but rather a complete population of boys of that age in that area at that time.

Most of the boys (357, or 87\%) were White in appearance and of British origin, in the sense that they were being brought up by parents who had themselves been brought up in England, Scotland, or Wales. Of the remaining 54 boys, 12 were Afro-Caribbean, having at least one parent of West Indian (usually) or African origin. Of the remaining 42 boys of nonBritish origin, 14 had at least one parent from the North or South of Ireland, 12 had parents from Cyprus, and the other 16 boys were White and had at least one parent from another Western industrialized country.

On the basis of their fathers' occupations when they were aged 8,94\% of the boys could be described as working-class (categories III, IV or V on the Registrar General's scale, describing skilled, semi-skilled or unskilled manual workers), in comparison with the 
national figure of $78 \%$ at that time. The majority of the boys were living in conventional two-parent families with both a father and a mother figure; at age 8-9, only $6 \%$ of the boys had no operative father and only $1 \%$ had no operative mother. This was, therefore, overwhelmingly a traditional White, urban, working class sample of British origin.

\subsection{Interviews with the males}

The males have been interviewed nine times, at ages $8,10,14,16,18,21,25,32$, and 48 . At ages 8, 10, and 14, they were assessed in their schools. The tests in schools measured individual characteristics such as intelligence, attainment, personality, and psychomotor impulsivity. At all ages except 21 and 25, the aim was to interview all the males who were still alive, and it was always possible to interview a high proportion: 405 (99\%) at age 14, $399(97 \%)$ at age 16, $389(95 \%)$ at age 18, $378(94 \%)$ at age 32, and $365(93 \%)$ at age 48. The survey received ethical approval from the Ethics Committee of the Institute of Psychiatry, Kings College London. At age 48, 17 males had died, 5 could not be traced, and 24 refused, which meant that 365 out of 394 who were still alive were interviewed. Because of inadequate funding, only about half of the males were interviewed at age 21 , and about a quarter at age 25 .

In addition, the boys' teachers completed questionnaires when the boys were aged about 8, 10, 12, and 14. These furnished data about their troublesome and aggressive school behavior, their restlessness or poor concentration, their school attainments and their truancy. Ratings were also obtained from the boys' peers when they were in the primary schools at ages 8 and 10, about such topics as their daring, dishonesty, troublesomeness, and popularity. Only childhood measures from age 8-10 are analyzed in this article.

\subsection{Interviews with the parents}

Interviews with the parents were carried out by female social workers who visited their homes. These took place about once a year from when the boy was about 8 until when he was aged 14-15 and was in his last year of compulsory education. The primary informant

Revista Española de Investigación Criminológica 
was the mother, although many fathers were also seen. The parents provided details about such matters as family income, family size, their employment histories, their child-rearing practices (including attitudes, discipline, and parental harmony), their degree of supervision of the boy, and his temporary or permanent separations from them.

\subsection{Criminal record searches of the males}

Up to 1994, searches were carried out in the central Criminal Record Office or National Identification Service (CRO/NIS) at Scotland Yard in London to try to locate findings of guilt of the males and their biological relatives. The minimum age of criminal responsibility in England is 10. The Criminal Record Office contained records of all relatively serious offenses committed in Great Britain or Ireland, and also acted as a repository for records of minor juvenile offenses committed in London. In the case of 18 males who had emigrated outside Great Britain and Ireland by age 32, applications were made to search their criminal records in the eight countries where they had settled, and searches were actually carried out

in five countries. Seven males were counted as not at risk of conviction, because they emigrated permanently before age 21 , were not convicted, and were not searched abroad.

Between 1964 and 1979, paper records were consulted in the CRO/NIS at Scotland Yard. In 1979, the records were transferred on to microfiche, and microfiche records were then consulted in the CRO/NIS at Scotland Yard until 1994. However, from 1995, the microfiche collection was discontinued and all convictions were recorded on the Police National Computer (PNC). There was only limited copying of old records to the PNC, generally when a person received a new conviction.

The last search of conviction records in the CRO/NIS took place towards the end of 1994, when most of the males were aged 41. Convictions were counted for offenses committed up to the end of 1993, when most of the males were aged 40 (Farrington, Barnes, \& Lambert, 1996; Farrington et al., 1998). The recorded age of offending is defined here as the age at which an offense was committed, not the age on conviction. There can be delays of several months or even more than a year between offenses and convictions, making 
conviction ages different from offending ages. In investigating criminal careers, it is vital to study when offenses were committed.

Further searches of criminal records of the males took place in July 2002 and December 2004 in the PNC, by which time most of the males were aged 51. Many records of old convictions were not found in the PNC, and several convictions before 2002 were not found until the 2004 search, which covered NIS as well as PNC. The earliest date listed in the PNC was counted as the date on which an offence was committed. A Home Office report (Farrington et al., 2006) and many previous analyses were based on the criminal records up to age 50 derived from these searches. A further search of the PNC was completed in March 2011, when most males were aged 57. The criminal records of the G2 males are therefore now known up to age 56 (Farrington et al., 2013).

It was recently decided to count officially recorded cautions as well as convictions in the PNC, since cautions were routinely recorded on a national basis from 1995. In this article, therefore, "convictions" include officially recorded cautions. In total, 177 males were convicted up to age 56 ( $43.8 \%$ of 404 at risk) of a total of 909 offenses, including 51 cautions. Convictions were only counted if they were for "standard list" (more serious) offenses, thereby excluding minor crimes such as minor traffic infractions and simple drunkenness. The most common offenses that were included were thefts, burglaries and unauthorized takings of vehicles, although there were also quite a few offenses of violence, vandalism, fraud, and drug abuse. The definition of what is a "standard list" offense changed over time. In particular, common assault became a standard list offense in July 1995, drunk driving was added to the standard list from January 1996, and being drunk and disorderly was added in April 1997. All of these types of offenses were counted (see Farrington et al., 2014).

Offenses are defined as acts leading to convictions, and only offenses committed on different days were counted. Where two or more offenses were committed on the same day, only the most serious one was counted. This rule was adopted so that each separate incident could only yield one offense; if all offenses had been counted, the number of offenses would have been greater than the number of criminal incidents, and therefore the number of criminal incidents would have been overestimated. The most serious offense was defined as the one which received the most severe sentence or ---- where sentences were equal ---- the one with 
the longest maximum sentence. Most court appearances arose from only one offending day; the 909 recorded offenses up to age 56 corresponded to 826 separate occasions of conviction. Offenses "taken into consideration" were not counted.

The paper and microfiche records were extremely detailed (e.g. in their descriptions of the circumstances of offenses) but the computerized PNC records (actually the Home Office/Ministry of Justice extract from the PNC) are not. There were major problems in deciding whether a male found in a search was really our man, particularly in the case of people with common names and no middle names, and when there were slight differences in names or dates of birth between the PNC and our own records. Fortunately, it was possible to establish whether each male in the PNC data was our man unambiguously in all cases, using our prior searches, interview information and knowledge about the man's age and address (compared with his places of arrest and conviction, which were listed in the PNC record). In many cases, the male and/or his wife provided information about convictions in interviews. It would have been difficult to establish with certainty who was or was not our person in the PNC data in the absence of the interview data.

\subsection{Criminal record searches of the parents}

The fathers and mothers were repeatedly searched in the CRO/NIS between 1964 and 1994, when the average father (neglecting deaths) would have been 72 and the average mother would have been 69. Up to this time, 110 fathers (27.9\% out of 394 known) were convicted, with a total of 318 offenses, and 54 mothers (13.6\% out of 397$)$ were convicted, with a total of 258 offenses.

\subsection{Childhood factors}

In the CSDD, the large number of measured variables was reduced to a small number (24 in this analysis) that each seemed to measure a distinct theoretical construct. The 24 childhood factors, measured at ages 8-10, were classified into six categories. 
Attainment. Nonverbal intelligence was measured using Raven's Progressive Matrices test, while verbal intelligence was based on verbal comprehension and vocabulary tests. School attainment was derived from school records of English, arithmetic, and verbal reasoning tests, and the school track was the stream in which the boy was placed (based on his attainment).

Self-control. Daring was based on peer and parent ratings of taking many risks in traffic, climbing, exploring, and so on. Poor concentration and restlessness in class (hyperactivity) were rated by the boy's teachers, and impulsiveness (psychomotor clumsiness) was measured using the Porteus Maze, Spiral Maze, and Tapping tests.

Personality. Extraversion and neuroticism were measured using the New Junior Maudsley Inventory. Sample items were "I like to tell my friends all about things that happen to me" (true-extraversion) and "I worry about the little mistakes I make" (true-neuroticism). Popularity and dishonesty were measured using peer ratings, while troublesomeness (gets into trouble most) was based on both peer and teacher ratings.

Socioeconomic. Family income was derived from information given by parents to social workers. Similarly, the social workers enquired about the number of children in the family (including full biological siblings of the boy) and about the job of the family breadwinner (usually the father). The socioeconomic status (social class) of this job was rated on the Registrar General's scale, ranging from professional and managerial to unskilled manual jobs. The social workers also rated the quality of the housing, and the rating of poor housing identified dilapidated slum housing. Delinquency rates of the schools were obtained from the local education authority.

Parental. The convicted parent variable was based on the criminal record searches mentioned earlier. The age of the mother referred to her age at the time of her first birth, which was ascertained by the social workers. Parental interest in the boy's education was rated by the social workers (based on their interviews with the parents).

Family. The child-rearing assessment reflected warm or cold parental attitudes as well as harsh or erratic discipline. Parental disharmony identified parents who were in conflict. Parental supervision indicated whether the parents knew where the boy was when he was out, and parental separation identified boys who had been separated from a parent (usually 
the father) for at least three months for reasons other than death or hospitalization. All these variables were rated by the Study social workers and based on interviews with the parents (usually the mother).

These childhood factors have been investigated in numerous CSDD publications in the last 25 years as risk factors for official and self-reported violence (Farrington 1991, 1998, 2000a, 2001, 2006a, 2007b, 2012b), official and self-reported offending (Farrington, 1992b, 1994, 2000a, 2012a), chronic offenders (Farrington \& West, 1993), persistent young offenders (Farrington, 1999), bullying (Farrington, 1993b; Farrington \& Baldry, 2010), truancy (Farrington, 1996a), football violence and intimate partner violence (Farrington, 1994, 2006a; Theobald \& Farrington, 2012), dating violence (Theobald, Farrington, Ttofi, \& Crago, 2016), antisocial personality (Farrington, 1996b, 2000b), psychopathy (Farrington, 2006b, 2007c; Farrington \& Bergstrom, 2018, 2019), multiple problem youth (Farrington, 2002), physical health (Farrington, 1995a; Shepherd, Farrington, \& Potts, 2002, 2004), social failure (Farrington, 1993a), and late onset offenders (Zara \& Farrington, 2007, 2009, 2010). Generally, the most important childhood risk factors include a convicted parent, a disrupted family, low family income, large family size, low school attainment, high daring, and high troublesomeness. Childhood factors have only been investigated as protective factors in the two publications mentioned above (Farrington \& Ttofi, 2011; Farrington, Ttofi, \& Piquero, 2016).

\section{Results}

\subsection{Criminal careers}

As already mentioned, seven males were excluded from the analysis because they were not at risk of having a recorded conviction from age 21 . In the present article, a further 11 males were excluded because they were not at risk of having a recorded conviction from age 40. Seven died and four emigrated permanently before age 40. Of the remaining 393 males, 227 $(57.8 \%)$ were nonoffenders because they were not convicted up to age 56 (Table 1).

Table 1 shows the relationship between the age of the first offense and the age of the last offense for the 166 offenders. The most surprising feature of this table (in light of the 
widespread belief that offending is concentrated in the young ages) is that about one-third of all offenders (54, or 32.5\%) were still offending between ages 40 and 56. Furthermore, over two-thirds of these 54 offenders (37, or 68.5\%) were first convicted between ages 10 and 20, and therefore had very long criminal careers of at least 20 years. These males are termed the life-course-persistent offenders. Of the 125 males who were first convicted between ages 10 and 20, 50 (40\%) were last convicted also between ages 10 and 20. These males with short criminal careers are termed the early desisters. Another 38 of these males $(30.4 \%)$ were last convicted between ages 21 and 39. These males with longer criminal careers are termed the late desisters. We can be confident that they had indeed desisted because they had no further convictions in the 17 years up to age 56. The remaining 41 offenders, whose first conviction occurred at age 21 or later, are termed late onset offenders.

Table 1.

Age of first offense versus age of last offense

\begin{tabular}{|c|c|c|c|c|c|c|c|c|}
\hline \multirow[b]{2}{*}{$\begin{array}{l}\text { Age of first } \\
\text { Offense }\end{array}$} & \multicolumn{7}{|c|}{ Age of last offense } & \multirow[b]{2}{*}{ Total } \\
\hline & $10-13$ & $14-16$ & $17-20$ & 21-24 & 25-29 & 30-39 & $40+$ & \\
\hline $10-13$ & 4 & 5 & 4 & 5 & 5 & 4 & 8 & 35 \\
\hline $14-16$ & 0 & 12 & 6 & 5 & 4 & 5 & 19 & 51 \\
\hline $17-20$ & 0 & 0 & 19 & 6 & 3 & 1 & 10 & 39 \\
\hline $21-24$ & 0 & 0 & 0 & 5 & 1 & 0 & 3 & 9 \\
\hline $25-29$ & 0 & 0 & 0 & 0 & 6 & 1 & 1 & 8 \\
\hline $30-39$ & 0 & 0 & 0 & 0 & 0 & 11 & 4 & 15 \\
\hline $40+$ & 0 & 0 & 0 & 0 & 0 & 0 & 9 & 9 \\
\hline Total & 4 & 17 & 29 & 21 & 19 & 22 & 54 & 166 \\
\hline
\end{tabular}

Note: Excluding 11 offenders who were not at risk at age $40+$ because they died $(N=7)$ or emigrated $(N=4)$.

Table 2 shows criminal career features of these five categories of offenders. Not surprisingly, the life-course persistents (10.11) and late desisters (7.18) committed the most offenses on average, whereas the late onset offenders (2.12) and early desisters (2.24) committed relatively few offenses. More than half of the late onset offenders (58.5\%) committed only one offense, as did nearly half (48\%) of the early desisters. Contrary to Moffitt's (1993) theory, the average age of onset of the life-course-persistents (15.71) was similar to that of the early desisters (15.96) and slightly later than that of the late desisters

\section{Revista Española de Investigación Criminológica}


(15.14). However, as expected, the average criminal career duration was longest for the lifecourse-persistents (33.22 years) followed by the late desisters (11.90) the late onset offenders (3.92 years), and the early desisters (only 1.26 years).

It is interesting to study the overlap between chronic offenders and life-coursepersistent offenders. Following Wolfgang, Figlio, and Sellin (1972), who showed that 6\% of their cohort committed $52 \%$ of all offenses, chronic offenders are conventionally defined as the fraction of a cohort who commit at least half of all offenses. The 393 males in the present analysis committed a total of 846 offenses, but only 29 males (7.4\%), who each committed at least 10 offenses, accounted for 451 offenses (53.3\% of all offenses). Of these 29 chronic offenders, just over half (16, or 55.2\%) were life-course-persistent offenders, 11 $(37.9 \%)$ were late desisters, and two $(6.9 \%)$ were early desisters. This shows that chronic offenders are not necessarily life-course-persistent offenders.

\section{Table 2.}

Criminal careers of offender categories

\begin{tabular}{|l|c|c|c|c|c|}
\cline { 2 - 6 } \multicolumn{1}{c|}{} & $\begin{array}{c}\text { Non } \\
\text { offender }\end{array}$ & Late onset & $\begin{array}{c}\text { Early } \\
\text { desister }\end{array}$ & Late desister & $\begin{array}{c}\text { Life-course } \\
\text { persistent }\end{array}$ \\
\hline Number & 227 & 41 & 50 & 38 & 37 \\
Prevalence (\%) & 57.8 & 10.4 & 12.7 & 9.7 & 9.4 \\
Av.No. offenses & 0.0 & 2.12 & 2.24 & 7.18 & 10.11 \\
$\%$ One offense & NA & 58.5 & 48.0 & 0.0 & 0.0 \\
Av. Age onset & NA & 32.84 & 15.96 & 15.14 & 15.71 \\
Av. Age desistance & NA & 36.76 & 17.22 & 27.05 & 48.93 \\
Av. Career duration & NA & 3.92 & 1.26 & 11.90 & 33.22 \\
\hline
\end{tabular}

Note: $N A=$ Not applicable

\subsection{Childhood risk factors}

Table 3 shows the extent to which the 24 childhood risk factors were related to the five offender categories. Based on the chi-squared tests, the strongest relationships were for low attainment, high daring, high troublesomeness, poor housing, and a convicted parent. These childhood risk factors have been found to be strong predictors of convictions in many previous CSDD analyses. Three factors (high extraversion, high neuroticism, and low social class) did not significantly discriminate between the five categories. Low social class, in

\section{Revista Española de Investigación Criminológica}


particular, has not proved to be a significant predictor of convictions in previous CSDD analyses, although it did predict psychopathy (e.g., Farrington, 2006).

Table 3.

Risk factors for offender categories

\begin{tabular}{|c|c|c|c|c|c|c|}
\hline & $\begin{array}{l}\% \text { of } \\
\text { NO } \\
\text { (227) }\end{array}$ & $\begin{array}{l}\text { \% of } \\
\text { LO } \\
(41)\end{array}$ & $\begin{array}{l}\% \text { of } \\
\text { ED } \\
(50)\end{array}$ & $\begin{array}{l}\text { \% of } \\
\text { LD } \\
(38)\end{array}$ & $\begin{array}{l}\text { \% of } \\
\text { LCP } \\
(37)\end{array}$ & $p$ value \\
\hline \multicolumn{7}{|l|}{ Attainment } \\
\hline Low nonverbal IQ & 18.5 & 29.3 & 34.0 & 44.7 & 27.0 & .003 \\
\hline Low verbal IQ & 19.1 & 29.3 & 28.0 & 43.2 & 37.8 & .006 \\
\hline Low attainment & 14.9 & 29.7 & 29.2 & 48.6 & 36.4 & .0001 \\
\hline Low school track & 22.9 & 34.1 & 30.0 & 55.3 & 37.8 & .001 \\
\hline \multicolumn{7}{|l|}{ Self-control } \\
\hline High daring & 20.1 & 26.8 & 48.0 & 47.4 & 45.9 & .0001 \\
\hline High hyperactivity & 14.1 & 25.0 & 24.0 & 31.6 & 29.7 & .021 \\
\hline High impulsiveness & 19.4 & 34.1 & 36.0 & 28.9 & 32.4 & .037 \\
\hline \multicolumn{7}{|l|}{ Personality } \\
\hline High extraversion & 27.7 & 22.2 & 28.0 & 45.5 & 36.1 & NS \\
\hline High neuroticism & 25.9 & 30.6 & 40.0 & 36.4 & 30.6 & NS \\
\hline Low popularity & 28.7 & 31.6 & 21.3 & 48.6 & 42.9 & .036 \\
\hline High dishonesty & 16.6 & 32.4 & 33.3 & 36.4 & 43.8 & .001 \\
\hline High troublesomeness & 12.8 & 17.1 & 36.0 & 42.1 & 37.8 & .0001 \\
\hline \multicolumn{7}{|l|}{ Socioeconomic } \\
\hline Low social class & 16.7 & 22.0 & 16.0 & 26.3 & 29.7 & NS \\
\hline Low family income & 17.2 & 19.5 & 30.0 & 44.7 & 32.4 & .001 \\
\hline Poor housing & 27.8 & 51.2 & 60.0 & 44.7 & 37.8 & .0001 \\
\hline Large family size & 16.3 & 29.3 & 28.0 & 39.5 & 43.2 & .0003 \\
\hline High delinquency school & 14.1 & 25.6 & 25.5 & 45.9 & 24.2 & .0003 \\
\hline \multicolumn{7}{|l|}{ Parental } \\
\hline Convicted parent & 17.2 & 26.8 & 46.0 & 39.5 & 48.6 & .0001 \\
\hline Young mother & 16.7 & 22.0 & 22.0 & 36.8 & 37.8 & .007 \\
\hline Low interest in education & 13.1 & 12.8 & 17.4 & 32.4 & 30.3 & .014 \\
\hline \multicolumn{7}{|l|}{ Family } \\
\hline Poor child-rearing & 18.8 & 20.5 & 31.3 & 32.4 & 38.2 & .039 \\
\hline Parental conflict & 17.5 & 27.0 & 37.0 & 32.3 & 36.7 & .011 \\
\hline Separation & 14.1 & 29.3 & 32.0 & 28.9 & 40.5 & .0003 \\
\hline Poor supervision & 12.1 & 23.1 & 23.4 & 30.3 & 42.4 & .0002 \\
\hline
\end{tabular}

Notes: $\mathrm{NO}=$ Nonoffenders, $\mathrm{LO}=$ Late onset offenders, $\mathrm{ED}=$ Early desisters, $\mathrm{LD}=$ Late desisters, $\mathrm{LCP}=$ lifecourse-persistent offenders. $\mathrm{p}$ value based on chi-squared from $5 \times 2$ table. NS $=$ Not significant.

It would be expected that the life-course-persistent offenders would be the most risky, followed in order by the late desisters, the early desisters, the late onset offenders, and finally the nonoffenders. Remarkably, this pattern was found in only three cases: high dishonesty, poor child-rearing, and poor supervision. It would also be expected that the life-coursepersistent offenders would be more risky than the late desisters, but this was only found for 
the parental and family factors (in six out of seven cases). In 13 of the other 17 cases, the late desisters were more likely than the life-course-persistents to possess the risk factor. At least the expectation that the nonoffenders would be least risky was confirmed in all cases except four (high extraversion, low popularity, low social class, and low interest in education by parents).

Generally, the life-course-persistents were most likely to have experienced the parental and family risk factors, while the late desisters were most likely to have experienced the attainment and personality risk factors. The early desisters were most likely to have experienced high daring, high impulsiveness, high neuroticism, poor housing, and parental conflict, and least likely to have experienced low popularity and low social class. The late onset offenders were also likely to have experienced poor housing (more than the life-coursepersistents or the late desisters), and they were least likely to have experienced high extraversion and low parental interest in education.

\subsection{Childhood protective factors}

Table 4 shows the extent to which 22 protective factors were related to the five offender categories. (Two variables - poor housing and a convicted parent - were scored dichotomously and so their protective effects could not be investigated separately from their risk effects.) It can immediately be seen that relationships for protective factors tended to be less strong than for risk factors. Only two relationships were significant at $p=.0001$ (low daring and low troublesomeness), compared with five for risk factors. Nine relationships were not statistically significant at $\mathrm{p}=.05$ (high nonverbal IQ, high verbal IQ, low extraversion, high popularity, high social class, high family income, old mother, low parental conflict, and good supervision), compared with only three for the corresponding risk factors. 
Table 4.

Protective factors for offender categories

\begin{tabular}{|c|c|c|c|c|c|c|}
\hline & $\begin{array}{c}\text { \% of } \\
\text { NO } \\
\text { (227) }\end{array}$ & $\begin{array}{c}\text { \% of } \\
\text { LO } \\
\text { (41) }\end{array}$ & $\begin{array}{c}\text { \% of } \\
\text { ED } \\
(50)\end{array}$ & $\begin{array}{c}\text { \% of } \\
\text { LD } \\
\text { (38) }\end{array}$ & $\begin{array}{l}\text { \% of } \\
\text { LCP } \\
\text { (37) }\end{array}$ & $p$ value \\
\hline \multicolumn{7}{|l|}{ Attainment } \\
\hline High nonverbal IQ & 29.5 & 17.1 & 16.0 & 13.2 & 21.6 & .058 \\
\hline High verbal IQ & 29.3 & 22.0 & 18.0 & 13.5 & 13.5 & .061 \\
\hline High attainment & 33.0 & 29.7 & 16.7 & 13.5 & 9.1 & .004 \\
\hline High school track & 22.0 & 9.8 & 10.0 & 7.9 & 5.4 & .010 \\
\hline \multicolumn{7}{|l|}{ Self-control } \\
\hline Low daring & 37.9 & 19.5 & 8.0 & 15.8 & 13.5 & .0001 \\
\hline Low hyperactivity & 55.5 & 47.5 & 40.0 & 28.9 & 35.1 & .006 \\
\hline Low impulsiveness & 30.8 & 14.6 & 14.0 & 18.4 & 27.0 & .033 \\
\hline \multicolumn{7}{|l|}{ Personality } \\
\hline Low extraversion & 23.7 & 13.9 & 18.0 & 9.1 & 22.2 & NS \\
\hline Low neuroticism & 28.6 & 22.2 & 14.0 & 9.1 & 19.4 & .042 \\
\hline High popularity & 33.6 & 26.3 & 38.3 & 24.3 & 28.6 & NS \\
\hline Low dishonesty & 35.7 & 20.6 & 16.7 & 12.1 & 15.6 & .003 \\
\hline Low troublesomeness & 48.0 & 29.3 & 14.0 & 21.1 & 13.5 & .0001 \\
\hline \multicolumn{7}{|l|}{ Socioeconomic } \\
\hline High social class & 19.8 & 19.5 & 16.0 & 15.8 & 13.5 & NS \\
\hline High family income & 34.4 & 29.3 & 24.0 & 18.4 & 27.0 & NS \\
\hline Small family size & 42.7 & 26.8 & 36.0 & 31.6 & 13.5 & .006 \\
\hline Low delinquency school & 39.2 & 43.6 & 23.4 & 10.8 & 24.2 & .002 \\
\hline \multicolumn{7}{|l|}{ Parental } \\
\hline Old mother & 32.6 & 31.7 & 24.0 & 18.4 & 16.2 & NS \\
\hline High interest in education & 37.6 & 33.3 & 26.1 & 32.4 & 12.1 & .049 \\
\hline \multicolumn{7}{|l|}{ Family } \\
\hline Good child-rearing & 36.8 & 25.6 & 37.5 & 26.5 & 11.8 & .033 \\
\hline Low parental conflict & 35.3 & 34.2 & 27.7 & 25.0 & 12.9 & NS \\
\hline No separation & 65.6 & 48.8 & 50.0 & 44.7 & 43.2 & .007 \\
\hline Good supervision & 28.5 & 20.5 & 12.8 & 15.2 & 18.2 & .092 \\
\hline
\end{tabular}

Notes: $\mathrm{NO}=$ Nonoffenders, $\mathrm{LO}=$ Late onset offenders, ED = Early desisters, $\mathrm{LD}=$ Late desisters, $\mathrm{LCP}=$ lifecourse-persistent offenders. $\mathrm{p}$ value based on chi-squared from $5 \times 2$ table. NS $=$ Not significant.

It would be expected that the nonoffenders would be most likely to possess protective factors, followed in order by the late onset offenders, the early desisters, the late desisters, and lastly the life-course-persistent offenders. Remarkably, this pattern was found in only four cases (high attainment, high social class, old mother, low parental conflict). It would also be expected that the early desisters would be more likely than the life-course-persistents to have protective factors, but this was only found for the parental and family factors (in five out of six cases). In seven of the other 16 cases, the life-course-persistents were more likely 
to possess the protective factor. The expectation that the nonoffenders would be most likely to have protective factors was confirmed in all cases except three (high popularity, low delinquency rate school, good child-rearing).

Generally, the life-course-persistents were least likely to have experienced the parental and family protective factors, while the late desisters were least likely to have experienced the personality protective factors. The early desisters were most likely to have experienced high popularity and good child-rearing, and least likely to have experienced low daring, low impulsiveness, and good supervision. The late onset offenders were most likely to have attended low delinquency rate schools, and they were similar to the nonoffenders in having high attainment, low hyperactivity, high social class, old mothers, and low parental conflict.

\subsection{Predicting persisters and desisters}

Table 5 shows the risk and protective factors that predicted various categories of persisters and desisters. The first analysis (a) investigated predictors of late desisters compared with early desisters. For example, $48.6 \%$ of late desisters had low popularity, compared with $21.3 \%$ of early desisters. The strength of this relationship was measured using the odds ratio or OR (3.51). Conventionally, an OR of 2 or greater is considered to indicate a strong relationship (Cohen, 1996), and all ORs of 2 or greater are shown in table 5. In addition, two ORs are shown that were close to 2 and not far off statistical significance. One-tailed tests were used because of the clear directional predictions (i.e. that persisters would be more likely than desisters to possess risk factors and less likely than desisters to possess protective factors). Few results are statistically significant because of the small numbers in these analyses. 
Table 5.

Risk and protective factors for persisters and desisters

\begin{tabular}{|c|c|c|c|c|}
\hline (a) LD (38) vs. ED (50) & \% of ED & \% of LD & Odds Ratio & $p$ value \\
\hline Low popularity & 21.3 & 48.6 & 3.51 & .005 \\
\hline Low school track & 30.0 & 55.3 & 2.88 & .009 \\
\hline Low delinquency school & 23.4 & 10.8 & 2.52 & .072 \\
\hline High delinquency school & 25.5 & 45.9 & 2.48 & .026 \\
\hline Low attainment & 29.2 & 48.6 & 2.30 & .034 \\
\hline Low interest in education & 17.4 & 32.4 & 2.27 & .062 \\
\hline Low extraversion & 18.0 & 9.1 & 2.20 & NS \\
\hline High extraversion & 28.0 & 45.5 & 2.14 & .054 \\
\hline Young mother & 22.0 & 36.8 & 2.07 & .064 \\
\hline Low verbal IQ & 28.0 & 43.2 & 1.96 & .071 \\
\hline (b) LCP (37) vs. LD (38) & $\%$ of LD & \% of LCP & Odds Ratio & $p$ value \\
\hline High interest in education & 32.4 & 12.1 & 3.47 & .027 \\
\hline Small family size & 31.6 & 13.5 & 2.95 & .034 \\
\hline Good child-rearing & 26.5 & 11.8 & 2.70 & .066 \\
\hline Low parental conflict & 25.0 & 12.9 & 2.25 & NS \\
\hline (c) LCPLD (75) vs. ED (50) & $\%$ of ED & \% of LCPLD & Odds Ratio & $p$ value \\
\hline Low popularity & 21.3 & 45.8 & 3.13 & .004 \\
\hline Good child-rearing & 37.5 & 19.1 & 2.54 & .015 \\
\hline Low interest in education & 17.4 & 31.3 & 2.17 & .050 \\
\hline Young mother & 22.0 & 37.3 & 2.11 & .037 \\
\hline Low social class & 16.0 & 28.0 & 2.04 & .063 \\
\hline Low school track & 30.0 & 46.7 & 2.04 & .032 \\
\hline Small family size & 36.0 & 22.7 & 1.92 & .055 \\
\hline (d) LCP (37) vs. EDLD (88) & $\%$ of EDLD & \% of LCP & Odds Ratio & $p$ value \\
\hline Good child-rearing & 32.9 & 11.8 & 3.68 & .013 \\
\hline Small family size & 34.1 & 13.5 & 3.31 & .012 \\
\hline High interest in education & 28.8 & 12.1 & 2.93 & .034 \\
\hline Low parental conflict & 26.6 & 12.9 & 2.44 & .067 \\
\hline Poor supervision & 26.3 & 42.4 & 2.07 & .047 \\
\hline
\end{tabular}

Notes: LCP = Life-course-persistent offenders, LD = Late desisters, LCPLD = Life-course-persistent offenders plus late desisters, ED = Early desisters, EDLD = Early desisters plus late desisters. $\mathrm{p}$ values one-tailed. $\mathrm{NS}=$ Not significant.

Revista Española de Investigación Criminológica

Artículo 1, Número 17 (2019)

www.criminologia.net

ISSN: 1696-9219 
Most of the variables that predicted late desisters compared with early desisters were risk factors: low popularity, low school track, high delinquency rate school, low school attainment, low parental interest in education, high extraversion, a young mother, and low verbal IQ. Only two predictors were protective factors (low delinquency rate school and low extraversion), and the prediction was not statistically significant in either case. Also, in both cases the corresponding risk factor (high delinquency rate school and high extraversion) was more significant. Therefore, it seems that whether a male desists early or later depends on risk factors rather than protective factors.

The second analysis (b) investigated predictors of life-course-persistent offenders compared with late desisters. Once again, few results are statistically significant because of the small numbers in this analysis. However, it was noteworthy that the four strongest predictors were all protective factors: high parental interest in education, small family size, good child-rearing, and low parental conflict. Therefore, it may be that whether a male becomes a life-course-persister or desists earlier depends on protective factors rather than risk factors.

The third analysis (c) investigated predictors of persistence after age 20 (the lifecourse-persistent offenders plus the late desisters) compared with early desisters. The majority of the most important predictors were risk factors: low popularity, low parental interest in education, a young mother, low social class, and low school track. Four of these risk factors (all except low social class) were also important predictors of late desisters versus early desisters in analysis (a). Only two protective factors (good child-rearing and small family size) were important predictors, and small family size was the weakest of these predictors. This confirms the earlier conclusion that whether a male desists early depends on risk factors rather than protective factors.

The fourth analysis (d) investigated predictors of life-course-persistent offenders compared with all other offenders who were convicted up to age 20 (early desisters plus late desisters). The four most important predictors were all protective factors: good child-rearing, small family size, high parental interest in education, and low parental conflict. The same four protective factors were the most important predictors of life-course-persistent offenders compared with late desisters. This confirms the earlier conclusion that whether a male

Revista Española de Investigación Criminológica 
becomes a life-course-persister or desists earlier depends on protective factors rather than risk factors.

\section{Conclusions}

The argument that childhood risk factors do not predict later persistence or desistance in offending can be firmly rejected. Several of the most important childhood risk factors, that have previously been shown to predict offenders compared with nonoffenders in the CSDD, also predicted whether an early onset offender up to age 20 persisted after this age or desisted. Individual and school risk factors were the most important, including low popularity, low school attainment, low parental interest in education, and attending a high delinquency rate school. It may be suggested that school failure is the most important childhood risk factor that predicts persistence in offending after age 20 .

The most unexpected finding of this research was that whether an offender became a life-course-persister or desisted earlier depended on childhood protective factors rather than risk factors. The most important protective factors were all connected with the family: good child-rearing, high parental interest in education, small family size, and low parental conflict. It may be suggested that a good family is the most important childhood factor that encourages desistance and protects offenders from persisting in offending in their 40s and 50s. 


\section{References}

Barnett, A., Blumstein, A., \& Farrington, D.P. (1989). A prospective test of a criminal career model. Criminology, 27, 373-388.

Basto-Pereira, M., Começanha, R., Ribeiro, S., \& Maia, A. (2015). Long-term predictors of crime desistance in juvenile delinquents: A systematic review of longitudinal studies. Aggression and Violent Behavior, 25, $332-342$.

Blumstein, A., Cohen, J., Roth, J.A., \& Visher, C.A. (Eds.) (1986). Criminal careers and “career criminals" (2 vols.). Washington, DC: National Academy Press.

Blumstein, A., \& Nakamura, K. (2009). Redemption in the presence of widespread criminal background checks. Criminology, 47, 327-360.

Bushway, S. D., Nieuwbeerta, P., \& Blokland, A. (2011). The predictive value of criminal background checks: Do age and criminal history affect time to redemption? Criminology, 49, 27-60.

Bushway, S. D., \& Paternoster, R. (2013). Desistance from crime: a review and ideas for moving forward. In C. L. Gibson \& M. D. Krohn (Eds.), Handbook of life-course criminology (pp. 213-231). New York: Springer.

Cohen, P. (1996). Childhood risks for young adult symptoms of personality disorder: Method and substance. Multivariate Behavioral Research, 31, 121-148.

Cottle, C.C., Lee, R.J., \& Heilbrun, K. (2001). The prediction of criminal recidivism in juveniles: A meta-analysis. Criminal Justice and Behavior, 28, 367 - 394.

Farrington, D. P. (1991). Childhood aggression and adult violence: Early precursors and later life outcomes. In D. J. Pepler \& K. H. Rubin (Eds.), The development and treatment of childhood aggression (pp. 5-29). Hillsdale, NJ: Lawrence Erlbaum.

Farrington, D. P. (1992a). Criminal career research in the United Kingdom. British Journal of Criminology 32, 521-536.

Farrington, D. P. (1992b). Juvenile delinquency. In J. C. Coleman (Ed.), The school years (2nd ed., pp. 123-163). London: Routledge.

Farrington, D. P. (1993a). Childhood origins of teenage antisocial behaviour and adult social dysfunction. Journal of the Royal Society of Medicine, 86, 13-17.

Farrington, D. P. (1993b). Understanding and preventing bullying. In M. Tonry (Ed.) Crime and justice (vol. 17, pp. 381-458). Chicago: University of Chicago Press.

Farrington, D. P. (1994). Childhood, adolescent and adult features of violent males. In L. R. Huesmann (Ed.), Aggressive behavior: Current perspectives (pp. 215-240). New York: Plenum.

Farrington, D.P. (1995a). Crime and physical health: Illnesses, injuries, accidents and offending in the Cambridge Study. Criminal Behaviour and Mental Health, 5, 261-278.

Farrington, D.P. (1995b). The development of offending and antisocial behaviour from childhood: Key findings from the Cambridge Study in Delinquent Development. Journal of Child Psychology and Psychiatry, 36, 929-964.

Farrington, D.P. (1996a). Later life outcomes of truants in the Cambridge Study. In I. Berg, \& J. Nursten (Eds.), Unwillingly to school (4th ed., pp. 96-118). London: Gaskell.

Farrington, D.P. (1996b). Psychosocial influences on the development of antisocial

Revista Española de Investigación Criminológica

Artículo 1, Número 17 (2019)

www.criminologia.net

ISSN: 1696-9219 
personality. In G. Davies, S. Lloyd-Bostock, M. McMurran, \& C. Wilson (Eds.), Psychology, law and criminal justice: International developments in research and practice. (pp. 424-444). Berlin, Germany: de Gruyter.

Farrington, D. P. (1998). Predictors, causes, and correlates of youth violence. In M. Tonry \& M. H. Moore (Eds.), Youth violence (pp. 421-475). Chicago: University of Chicago Press.

Farrington, D. P. (1999). Predicting persistent young offenders. In G. L. McDowell \& J. S. Smith (Eds.) Juvenile delinquency in the United States and the United Kingdom (pp. 3-21). London: Macmillan.

Farrington, D. P. (2000a). Adolescent violence: Findings and implications from the Cambridge Study. In G. Boswell (Ed.), Violent children and adolescents: Asking the question why (pp. 19-35). London: Whurr.

Farrington, D. P. (2000b). Psychosocial predictors of adult antisocial personality and adult convictions. Behavioral Sciences and the Law, 18, 605-622.

Farrington, D. P. (2001). Predicting adult official and self-reported violence. In G-F. Pinard \& L. Pagani (Eds.), Clinical assessment of dangerousness: Empirical contributions (pp. 66-88). Cambridge, UK: Cambridge University Press.

Farrington, D.P. (2002). Multiple risk factors for multiple problem violent boys. In R. R. Corrado, R. Roesch, S. D. Hart, \& J. K. Gierowski, J.K. (Eds.), Multi-problem violent youth: A foundation for comparative research on needs, interventions and outcomes (pp. 23-34). Amsterdam, Netherlands: IOS Press.

Farrington, D. P. (2003). Key results from the first 40 years of the Cambridge Study in Delinquent Development. In T. P. Thornberry \& M. D. Krohn (Eds.), Taking stock of delinquency: An overview of findings from contemporary longitudinal studies (pp. 137-183). New York: Kluwer/Plenum.

Farrington, D. P. (2005). The Integrated Cognitive Antisocial Potential (ICAP) theory. In D. P. Farrington (Ed.), Integrated developmental and life-course theories of offending (pp. 73-92). New Brunswick, NJ: Transaction.

Farrington, D. P. (2006a). Comparing football hooligans and violent offenders: Childhood, adolescent, teenage, and adult features. Monatsschrift fur Kriminologie und Strafrechtsreform (Journal of Criminology and Penal Reform), 89, 193-205.

Farrington, D. P. (2006b). Family background and psychopathy. In C. J. Patrick (Ed.), Handbook of psychopathy (pp. 229-250). New York: Guilford.

Farrington, D. P. (2007a). Advancing knowledge about desistance. Journal of Contemporary Criminal Justice, 23, 125-134.

Farrington, D. P. (2007b). Origins of violent behavior over the life span. In D. J. Flannery, A. J. Vaszonyi, \& I. D. Waldman (Eds.), The Cambridge handbook of violent behavior and aggression (pp. 19-48). Cambridge, UK: Cambridge University Press.

Farrington, D. P. (2007c). Social origins of psychopathy. In A.R. Felthous \& H. Sass (Eds.) International handbook on psychopathic disorders and the law, Vol. 1: Diagnosis and treatment (pp. 319-334). New York: Wiley.

Farrington, D. P. (2012a). Childhood risk factors for young adult offending: Onset and persistence. In F. Lösel, A. Bottoms, \& D. P. Farrington (Eds.), Young adult offenders: Lost in transition? (pp. 48-64). Abingdon, UK: Routledge.

Revista Española de Investigación Criminológica

Artículo 1, Número 17 (2019)

www.criminologia.net

ISSN: 1696-9219 
Farrington, D. P. (2012b). Predictors of violent young offenders. In B. C. Feld \& D. M. Bishop (Eds.), The Oxford handbook on juvenile crime and juvenile justice (pp.146171). Oxford, UK: Oxford University Press.

Farrington, D. P. (2015). Prospective longitudinal research on the development of offending. Australian and New Zealand Journal of Criminology, 48, 314-335.

Farrington, D. P., \& Baldry, A. C. (2010). Individual risk factors for school bullying. Journal of Aggression, Conflict and Peace Research, 2, 4-16.

Farrington, D. P., Barnes, G., \& Lambert, S. (1996). The concentration of offending in families. Legal and Criminological Psychology, 1, 47-63.

Farrington, D. P., \& Bergstrom, H. (2018). Family background and psychopathy. In C. J. Patrick (Ed.), Handbook of Psychopathy (2 ${ }^{\text {nd }}$ ed.). New York: Guilford Press (pp. 354-379).

Farrington, D. P., \& Bergstrom, H. (2019). Social origins of psychopathy. In A.R. Felthous \& H. Sass (Eds.), International handbook on psychopathic disorders and the law, vol. 1: Diagnosis and treatment ( $2^{\text {nd }}$ ed.) New York: Wiley, in press.

Farrington, D. P., Coid, J. W., Harnett, L., Jolliffe, D., Soteriou, N., Turner, R., \& West, D. J. (2006). Criminal Careers up to age 50 and life success up to age 48: New findings from the Cambridge Study in Delinquent Development. London: Home Office (Research Study No. 299).

Farrington, D. P., Coid, J. W., \& West, D. J. (2009). The development of offending from age 8 to age 50: Recent results from the Cambridge Study in Delinquent Development. Monatsschrift fur Kriminologie und Strafrechtsreform (Journal of Criminology and Penal Reform), 92, 160-173.

Farrington, D. P., Gallagher, B., Morley, L., St Ledger, R.J. \& West, D.J. (1986). Unemployment, school leaving and crime. British Journal of Criminology 26, 335-356.

Farrington, D.P., \& Hawkins, J.D. (1991). Predicting participation, early onset, and later persistence in officially recorded offending. Criminal Behaviour and Mental Health, 1, 1-33.

Farrington, D. P., Lambert, S., \& West, D. J. (1998). Criminal careers of two generations of family members in the Cambridge Study in Delinquent Development. Studies on Crime and Crime Prevention, 7, 85-106.

Farrington, D. P. \& Loeber, R. (2000). Some benefits of dichotomization in psychiatric and criminological research. Criminal Behaviour and Mental Health, 10, 100-122.

Farrington, D. P., MacLeod, J. F., \& Piquero, A. R. (2016). Mathematical models of criminal careers: Deriving and testing quantitative predictions. Journal of Research in Crime and Delinquency, 53, 336-355.

Farrington, D. P., Piquero, A. R., \& Jennings, W. G. (2013). Offending from childhood to late middle age: Recent results from the Cambridge Study in Delinquent Development. New York: Springer.

Farrington, D. P. \& Ttofi, M. M. (2011). Protective and promotive factors in the development of offending. In T. Bliesener, A. Beelman, \& M. Stemmler (Eds.), Antisocial behavior and crime: Contributions of developmental and evaluation research to prevention and intervention (pp. 71-88). Cambridge, MA: Hogrefe. 
Farrington, D. P., Ttofi, M. M., \& Coid, J. W. (2009). Development of adolescence-limited, late-onset and persistent offenders from age 8 to age 48. Aggressive Behavior, 35, 150-163.

Farrington, D. P., Ttofi, M. M., \& Crago, R. V. (2017). Intergenerational transmission of convictions for different types of offenses. Victims and Offenders, 12, 1-20.

Farrington, D.P., Ttofi, M.M., \& Crago, R.V. (2018). Intergenerational transmission of self-reported offending in the Cambridge Study in Delinquent Development. In V. I. Eichelsheim \& S.G.A. Van de Weijer (Eds.), Intergenerational continuity of criminal and antisocial behaviour: An international overview of studies (pp. 115136). Abingdon, UK: Routledge

Farrington, D. P., Ttofi, M. M., Crago, R. V., \& Coid, J. W. (2014). Prevalence, frequency, onset, desistance and criminal career duration in self-reports compared with official records. Criminal Behaviour and Mental Health, 24, 241-253.

Farrington, D. P., Ttofi, M. M., Crago, R. V., \& Coid, J. W. (2015). Intergenerational similarities in risk factors for offending. Journal of Developmental and Life-Course Criminology, 1, 48-62.

Farrington, D.P., Ttofi, M.M., \& Piquero, A.R. (2016). Risk, promotive, and protective factors in youth offending: Results from the Cambridge Study in Delinquent Development. Journal of Criminal Justice, 45, 63-70.

Farrington, D. P., \& West, D. J. (1981). The Cambridge Study in Delinquent Development. In S.A. Mednick \& A.E. Baert (Eds.), Prospective longitudinal research: An empirical basis for the primary prevention of psychosocial disorders (pp. 137-145). Oxford, UK: Oxford University Press.

Farrington, D. P., \& West, D.J. (1990). The Cambridge Study in Delinquent Development: A long-term follow-up of 411 London males. In H.J. Kerner \& G. Kaiser (Eds.), Kriminalitat: Personlichkeit, lebensgeschichte und verhalten (Criminality: Personality, behaviour and life history)(pp. 115-138). Berlin, Germany: Springer-Verlag.

Farrington, D.P., \& West, D.J. (1993). Criminal, penal and life histories of chronic offenders: Risk and protective factors and early identification. Criminal Behaviour and Mental Health, 3, 492-523.

Farrington, D. P., \& West, D. J. (1995). Effects of marriage, separation and children on offending by adult males. In J. Hagan (Ed.), Current perspectives on aging and the life cycle. Vol. 4: Delinquency and disrepute in the life course (pp. 249-281). Greenwich, CT: JAI Press.

Gendreau, P., Little, T., \& Goggin, C. (1996). A meta-analysis of the predictors of adult offender recidivism: What works! Criminology, 34, 575-607.

Horney, J., Tolan, P., \& Weisburd, D. (2012). Contextual influences. In R. Loeber \& D. P. Farrington (Eds.), From juvenile delinquency to adult crime (pp. 86-117). New York: Oxford University Press.

Jennings, W. G., \& Fox, B. H. (2019). Acceleration, deceleration, escalation, and de-escalation. In D.P. Farrington, L. Kazemian, \& A.R. Piquero (Eds.), The Oxford handbook of developmental and life-course criminology (pp. 70-80). New York: Oxford University Press. 
Jolliffe, D., Farrington, D.P., Piquero, A.R., Loeber, R., \& Hill, K.G. (2017). Systematic review of early risk factors for life-course-persistent, adolescence-limited and lateonset offenders in prospective longitudinal studies. Aggression and Violent Behavior, $33,15-23$.

Jolliffe, D. Farrington, D. P., Piquero, A. R., Macleod, J. F., \& Van de Weijer, S. (2017). Prevalence of life-course persistent, adolescence-limited and late-onset offenders: A systematic review of prospective longitudinal studies. Aggression and Violent Behavior, 33, 4-14.

Kazemian L., \& Farrington, D. P. (2006). Exploring residual career length and residual number of offenses for two generations of repeat offenders. Journal of Research in Crime and Delinquency, 43, 89-113.

Kazemian, L., \& Farrington, D. P. (2015). The developmental evidence base: Desistance. In D.A. Crighton \& G.J. Towl (Eds.), Forensic psychology (2 ${ }^{\text {nd }}$ ed., pp. 183-199). Chichester, UK: Wiley.

Kazemian, L., \& Farrington, D.P. (2018). Advancing knowledge about residual criminal careers: A follow-up to age 56 from the Cambridge Study in Delinquent Development. Journal of Criminal Justice, 57, 1-10.

Kazemian, L., Farrington, D. P., \& LeBlanc, M. (2009). Can we make accurate long-term predictions of patterns of de-escalation in offending behavior? Journal of Youth and Adolescence, 38, 384-400.

Kazemian, L., LeBlanc, M., Farrington, D. P., \& Pease, K. (2007). Patterns of residual criminal careers among a sample of adjudicated French-Canadian males. Canadian Journal of Criminology and Criminal Justice, 49, 307-340.

Kirk, D. S. (2012). Residential change as a turning point in the life course of crime: Desistance or temporary cessation? Criminology, 50, 329-357.

Kirk, D. S. (2019). The effects of neighborhood context and residential mobility on criminal persistence and desistance. In D.P. Farrington, L. Kazemian, \& A.R. Piquero (Eds.), The Oxford handbook of developmental and life-course criminology (pp. 515-535). New York: Oxford University Press.

Kurlychek, M. C., Brame, R., \& Bushway, S. D. (2006). Scarlet letters and recidivism: Does an old criminal record predict future offending? Criminology and Public Policy, 5, 483-504.

Laub, J. H., \& Sampson, R. J. (2003). Shared beginnings, divergent lives: Delinquent boys to age 70. Cambridge, MA: Harvard University Press.

Loeber, R., Farrington, D. P., Stouthamer-Loeber, M., \& White, H. R. (2008). Violence and serious theft: Development and prediction from childhood to adulthood. New York: Routledge.

Loeber, R., Stouthamer-Loeber, M., Van Kammen, W., \& Farrington, D.P. (1991). Initiation, escalation, and desistance in juvenile offending and their correlates. Journal of Criminal Law and Criminology, 82, 36-82.

McGee, T. R., \& Moffitt. T. E. (2019). The developmental taxonomy. In D.P. Farrington, L. Kazemian, \& A.R. Piquero (Eds.), The Oxford handbook of developmental and life-course criminology (pp. 149-158). New York: Oxford University Press. 
Moffitt, T. E. (1993). Adolescence-limited and life-course-persistent antisocial behavior: A developmental taxonomy. Psychological Review, 100, 674-701.

Moffitt, T. E. (2018). Male antisocial behaviour in adolescence and beyond. Nature Human Behaviour, 2(3), 177-186.

Nagin, D. S., \& Land, K. C. (1993). Age, criminal careers, and population heterogeneity: Specification and estimation of a nonparametric, mixed Poisson model. Criminology, 31, 327-362.

Osborn, S. G. (1980). Moving home, leaving London and delinquent trends. British Journal of Criminology, 20, 54-61.

Piquero, A. R., Farrington, D. P., \& Blumstein, A. (2003). The criminal career paradigm. In M. Tonry (Ed.), Crime and justice, vol. 30 (pp. 359-506). Chicago: University of Chicago Press.

Piquero, A. R., Farrington, D. P., \& Blumstein, A. (2007). Key issues in criminal career research: New analyses of the Cambridge Study in Delinquent Development. Cambridge, UK: Cambridge University Press.

Piquero, A. R., Sullivan, C. J., \& Farrington, D. P. (2010). Assessing differences between short-term, high-rate offenders and long-term, low-rate offenders. Criminal Justice and Behavior, 37, 1309-1329.

Sampson, R. J., \& Laub, J. H. (1993). Crime in the making: Pathways and turning points through life. Cambridge, MA: Harvard University Press.

Sampson, R. J., \& Laub, J. H. (2003). Life-course desisters? Trajectories of crime among delinquent boys followed to age 70. Criminology, 41, 301-339.

Sampson, R. J., \& Laub, J. H. (2005). A general age-graded theory of crime: Lessons learned and the future of life-course criminology. In D. P. Farrington (Ed.), Integrated developmental and life-course theories of offending (pp. 165-181). New Brunswick, NJ: Transaction.

Savolainen, J. (2009). Work, family and criminal desistance: Adult social bonds in a Nordic welfare state. British Journal of Criminology, 49, 285-304.

Savolainen, J., Aaltonen, M., and Skardhamar, T. (2019). Employment, crime, and the life course. In D.P. Farrington, L. Kazemian, \& A.R. Piquero (Eds.), The Oxford handbook of developmental and life-course criminology (pp. 495-514). New York: Oxford University Press.

Shepherd, J. P., Farrington, D. P., \& Potts, A. J. C. (2002). Relations between offending, injury and illness. Journal of the Royal Society of Medicine, 95, 539-544.

Shepherd, J. P., Farrington, D. P., \& Potts, A. J. C. (2004). Impact of antisocial lifestyle on health. Journal of Public Health Medicine, 26, 347-352.

Skardhamar, T. (2010). Distinguishing facts and artifacts in group-based modeling. Criminology, 48, 295-320.

Skardhamar, T., \& Savolainen, J. (2014). Changes in criminal offending around the time of job entry: A study of employment and desistance. Criminology, 52, 263-291.

Theobald, D. \& Farrington, D. P. (2009). Effects of getting married on offending: Results from a prospective longitudinal survey of males. European Journal of Criminology, 6, 496-516.

Theobald, D., \& Farrington, D. P. (2010). Should policy implications be drawn from research 
on the effects of getting married on offending? European Journal of Criminology, 7, 239-247.

Theobald, D., \& Farrington, D. P. (2011). Why do the crime-reducing effects of marriage vary with age? British Journal of Criminology, 51, 136-158.

Theobald, D., \& Farrington, D. P. (2012). Child and adolescent predictors of male intimate partner violence. Journal of Child Psychology and Psychiatry, 53, 1242-1249.

Theobald, D., \& Farrington, D. P. (2013). The effects of marital breakdown on offending: Results from a prospective longitudinal survey of males. Psychology, Crime and Law, 19, 391-408.

Theobald, D., Farrington, D. P., \& Piquero, A. R. (2015). Does the birth of a first child reduce the father's offending? Australian and New Zealand Journal of Criminology, 48, 323.

Theobald, D., Farrington, D.P. and Piquero, A.R. (2019). The impact of changes in family situations on persistence and desistance from crime. In D.P. Farrington, L. Kazemian, \& A.R. Piquero (Eds.), The Oxford handbook of developmental and lifecourse criminology (pp. 475-494). New York: Oxford University Press.

Theobald, D., Farrington, D.P., Ttofi, M. M., \& Crago, R. V. (2016). Risk factors for dating violence versus cohabiting violence: Results from the third generation of the Cambridge Study in Delinquent Development. Criminal Behaviour and Mental Health, 26, 229-239.

Walker, K., Bowen, E., \& Brown, S. (2013). Psychological and criminological factors associated with desistance from violence: A review of the literature. Aggression and Violent Behavior, 18, 286 - 299.

West, D. J. (1969). Present conduct and future delinquency. London: Heinemann.

West, D. J. (1982). Delinquency: Its roots, careers and prospects. London: Heinemann.

West, D. J. \& Farrington, D. P. (1973). Who becomes delinquent? London: Heinemann.

West, D. J., \& Farrington, D. P. (1977). The delinquent way of life. London: Heinemann.

Whitten, T., McGee, T.R., Homel, R., Farrington, D.P., \& Ttofi, M.M. (2017). Disentangling operationalizations of persistent offending. Journal of Criminal Justice, 52, 22-33.

Whitten, T., McGee, T.R., Homel, R., Farrington, D.P., \& Ttofi, M.M. (2019).

Comparing the criminal careers and childhood risk factors of persistent, chronic, and persistent-chronic offenders. Australian and New Zealand Journal of Criminology, in press.

Wolfgang, M. E., Figlio, R. M., \& Sellin, T. (1972). Delinquency in a birth cohort. Chicago: University of Chicago Press.

Zara, G., \& Farrington, D. P. (2007). Early predictors of late onset offenders. International Annals of Criminology, 45, 37-56.

Zara, G., \& Farrington, D. P. (2009). Childhood and adolescent predictors of late onset criminal careers. Journal of Youth and Adolescence, 38, 287-300.

Zara, G., \& Farrington, D. P. (2010). A longitudinal analysis of early risk factors for adult onset offending: What predicts a delayed criminal career? Criminal Behaviour and Mental Health, 20, 257-273. 


\section{Acknowledgements}

For funding the CSDD, I am very grateful to the Home Office, the Department of Health, the Department of Education, the Rayne Foundation, the Barrow Cadbury Trust, and the SmithRichardson Foundation. An earlier version of this paper was presented at an international seminar on "Juvenile Delinquency: Desistance Processes, Identity and Social Bond" in Lisbon, Portugal, in December 2015.

David P. Farrington is Emeritus Professor of Psychological Criminology at Cambridge University. He has received the Stockholm Prize in Criminology, he has been President of the American Society of Criminology, and he is the first and only person to receive the four major awards of the American Society of Criminology: the Sutherland Award, the SellinGlueck Award, the Vollmer Award, and the Bloch Award. His major research interest is in developmental criminology, and he is Director of the Cambridge Study in Delinquent Development, which is a prospective longitudinal survey of over 400 London males from age 8 onwards. 